\title{
Fatty Acid, Isoprenoid Quinone and Polar Lipid Composition in the Classification of Curtobacterium and Related Taxa
}

\author{
By M. D. COLLINS, ${ }^{1 *}$ M. GOODFELLOW ${ }^{2}$ AND D. E. MINNIKIN ${ }^{3}$ \\ ${ }^{1}$ Department of Microbiology, School of Medicine and Biological Sciences, \\ University of Leicester, Leicester LE1 7RH \\ ${ }^{2}$ Department of Microbiology, University of Newcastle-upon-Tyne, \\ Newcastle-upon-Tyne NE1 $7 R U$ \\ ${ }^{3}$ Department of Organic Chemistry, University of Newcastle-upon-Tyne, \\ Newcastle-upon-Tyne NE1 $7 R U$
}

(Received 3 September 1979; revised 23 October 1979)

\begin{abstract}
Strains representing the taxa Curtobacterium, Brevibacterium saperdae, B. testaceum, Corynebacterium betae, Cor. nebraskense and Cor. oortii were degraded by acid methanolysis and the non-hydroxylated fatty acid esters released were examined by thin-layer and gasliquid chromatography. The major fatty acids in all strains were 12-methyltetradecanoic (anteiso $\mathrm{C}_{15}$ ) and 14-methylhexadecanoic (anteiso $\mathrm{C}_{17}$ ) acids which occurred together with other anteiso, iso and straight-chain acids. Polar lipids of the test strains were examined by two-dimensional thin-layer chromatography. All organisms possessed very characteristic polar lipid patterns consisting of diphosphatidylglycerol, phosphatidylglycerol and a number of uncharacterized glycolipids. The menaquinone components of the test strains facilitated their division into two groups containing, respectively, nine isoprene units (viz. Curtobacterium citreum, Curt. luteum, Corynebacterium betae, Cor. flaccumfaciens, Cor. oortii, Cor. poinsettiae and Cor. nebraskense) and eleven and twelve isoprene units (viz. Brevibacterium saperdae, $B$. testaceum). The results of the present study indicate that the genus Curtobacterium as presently recognized is a heterogeneous taxon containing two distinct centres of variation.
\end{abstract}

\section{INTRODUCTION}

The genus Curtobacterium was proposed by Yamada \& Komagata (1972) to accommodate certain 'motile brevibacteria' and the phytopathogens Corynebacterium flaccumfaciens and Cor. poinsettiae. Subsequent studies have indicated that Cor. betae should also be included in the genus (Jones, 1975; Kcddie \& Cure, 1977). The main distinguishing features for curtobacteria are the presence of ornithine in the cell wall, DNA containing 66 to $71 \mathrm{~mol} \%$ $\mathrm{G}+\mathrm{C}$, and slow and weak acid production from some carbohydrates. Additional criteria are required to tighten the genus description and to help separate Curtobacterium from other ornithine-containing coryneform taxa such as Cellulomonas.

Recently, lipid composition has been found to be of value in the classification and identification of coryneform bacteria (Minnikin et al., 1978). The most productive lipid studies on curtobacteria have involved the analyses of isoprenoid quinones (Yamada et al., 1976; Collins et al., 1979). The fatty acid and polar lipid compositions of curtobactoria have received less attention (Tadayon \& Carroll, 1971; Komura $c t$ al., 1975) and it is not known 
whether they are of value in the classification of the group. In the present study, the isoprenoid quinones, polar lipids and fatty acid profiles of representative strains of curtobacteria, Brevibacterium saperdae (Lysenko, 1959), B. testaceum (Komagata et al., 1964), Cor. nebraskense (Vidaver \& Mandel, 1974) and Cor. oortii (Saaltink \& Mass Geesteranus, 1969) were examined in an attempt to clarify their taxonomy.

\section{METHODS}

Cultures and cultivation. The test strains listed in Table 1 were maintained on Dorset Egg (Cowan, 1974) and nutrient agar (Oxoid no. 2) slopes at room temperature, and cultivated in $400 \mathrm{ml}$ nutrient broth (Oxoid no. 2) at $30^{\circ} \mathrm{C}$ for $2 \mathrm{~d}$. The flasks were aerated by shaking in an orbital incubator at $150 \mathrm{rev}$. $\min ^{-1}$. Cultures were checked for purity at maximum growth, harvested by centrifugation $(5000 \mathrm{~g})$, washed with distilled water and freeze-dried.

Extraction and analysis of fatty acid methyl esters. Dried organisms $(50 \mathrm{mg})$ were examined using the acid methanolysis and thin-layer chromatography (t.l.c.) procedure described by Minnikin et al. (1975). Fatty acid methyl esters were purified by preparative t.l.c. on Merck silica gel $\mathbf{P F}_{254+366}$ plates $(1 \mathrm{~mm}$ thick) using petroleum ether (b.p. 60 to $80^{\circ} \mathrm{C}$ )/diethyl ether $(85: 15, \mathrm{v} / \mathrm{v})$ as developing solvent. The fatty acid methyl esters were located by viewing under ultraviolet light $(366 \mathrm{~nm})$ and eluted from the gel with chloroform. For the analysis of the fatty acid methyl esters, a Perkin-Elmer F11 flame-ionization gas chromatograph fitted with stainless steel columns ( $4 \mathrm{~mm}$ o.d.) was used, with nitrogen as carrier gas. Initial analyses were performed using both non-polar OV-1 (2 m, 2.5\% OV-1 silicone on 80 to 100 mesh Chromosorb G AW-DMCS, $180^{\circ} \mathrm{C}$; Phase Separations) and polar ( $2 \mathrm{~m}, 3 \%$ Silar 5CP on 80 to 100 mesh Gas Chrom Q, $160^{\circ} \mathrm{C}$; Applied Science Laboratories) columns. Resolution of mixtures of iso- and anteiso-methyl branched acids was achieved using a $6 \mathrm{~m}$ column packed with $10 \%$ Silar $10 \mathrm{C}$ on 100 to 120 mesh Gas Chrom Q (Applied Science Laboratories) at $210^{\circ} \mathrm{C}$. The identity of individual esters was established by comparison of the retention times with those of standard mixtures of straight-chain and monounsaturated esters and a branched-chain standard mixture (BC Mix-L; Applied Science Laboratories). Assignment of fatty acid esters was also assisted by calculation of equivalent chain lengths (Miwa et al., 1960) for each stationary phase employed. The relative proportions of the fatty acid esters were estimated by calculating the product of the retention time and peak height for each component and taking percentages of the sum of the products for all the components (Kates, 1972).

Extraction and analysis of polar lipids. Dry organisms $(100 \mathrm{mg})$ were extracted using a modification (Card, 1973; Minnikin et al., 1979) of the procedure of Bligh \& Dyer (1959). The polar lipids were analysed by twodimensional t.1.c. on Merck silica gel $\mathrm{H}$ plates $(0.5 \mathrm{~mm}$ thick) impregnated with sodium acetate (Minnikin \& Abdolrahimzadeh, 1971; Minnikin et al., 1979). Chromatograms were developed in the first dimension with chloroform/methanol/water $(65: 25: 4$, by vol.) and in the second with chloroform/aceticacid/methanol/ water $\left(80: 15: 12: 4\right.$, by vol.). Lipids were revealed by spraying the chromatograms with $40 \% \mathrm{H}_{2} \mathrm{SO}_{4}$ followed by charring at $180^{\circ} \mathrm{C}$. Specific spray reagents for lipid phosphate (Dittmer \& Lester, 1964), $\alpha$-glycols (periodate-Schiff) (Shaw, 1968), sugars ( $\alpha$-naphthol, and anisaldehyde $/ \mathrm{H}_{2} \mathrm{SO}_{4}$ ) (Jacin \& Mishkin, 1965; Stahl \& Kaltenbach, 1961) and free amino groups (ninhydrin in water-saturated butanol) were also used.

Extraction, purification and analysis of isoprenoid quinones. Dried organisms $(150 \mathrm{mg})$ were examined using the procedure described by Collins et al. (1977). Purified isoprenoid quinones were further examined by reverse phase partition chromatography using Merck HPTLC RP- $18 \mathrm{~F}_{254}$ reverse phase thin-layer plates $(10 \times 10 \mathrm{~cm})$ and a polar developing mixtureof acetone/water $(99: 1, \mathrm{v} / \mathrm{v})($ Collins et al., 1980). Separated components were detected under ultraviolet light $(254 \mathrm{~nm})$. Ultraviolet spectra of the quinones were recorded in iso-octane on a Perkin-Elmer (model 137UV) spectrophotometer. Mass spectra of the isoprenoid quinones were recorded on an AEI MS9 instrument using a direct insertion probe, an ionizing voltage of $70 \mathrm{eV}$ and a temperature range of 200 to $220^{\circ} \mathrm{C}$.

\section{RESULTS AND DISCUSSION}

Thin-layer chromatographic analysis of the whole-organism methanolysates of the test strains revealed single spots corresponding to non-hydroxylated long-chain fatty acid methyl esters (Minnikin et al., 1975, 1978). The non-hydroxylated fatty acids of the test strains were primarily anteiso- and iso-methyl branched-chain acids ( 90.5 to $99.4 \%$ ) although straightchain acids ( 0.6 to $9.5 \%$ ) were also present in small amounts (Table 1$)$. The major fatty acids in all strains were 14-methylhexadecanoic (anteiso $\mathrm{C}_{17}$ ) and 12-methyltetradecanoic (anteiso 


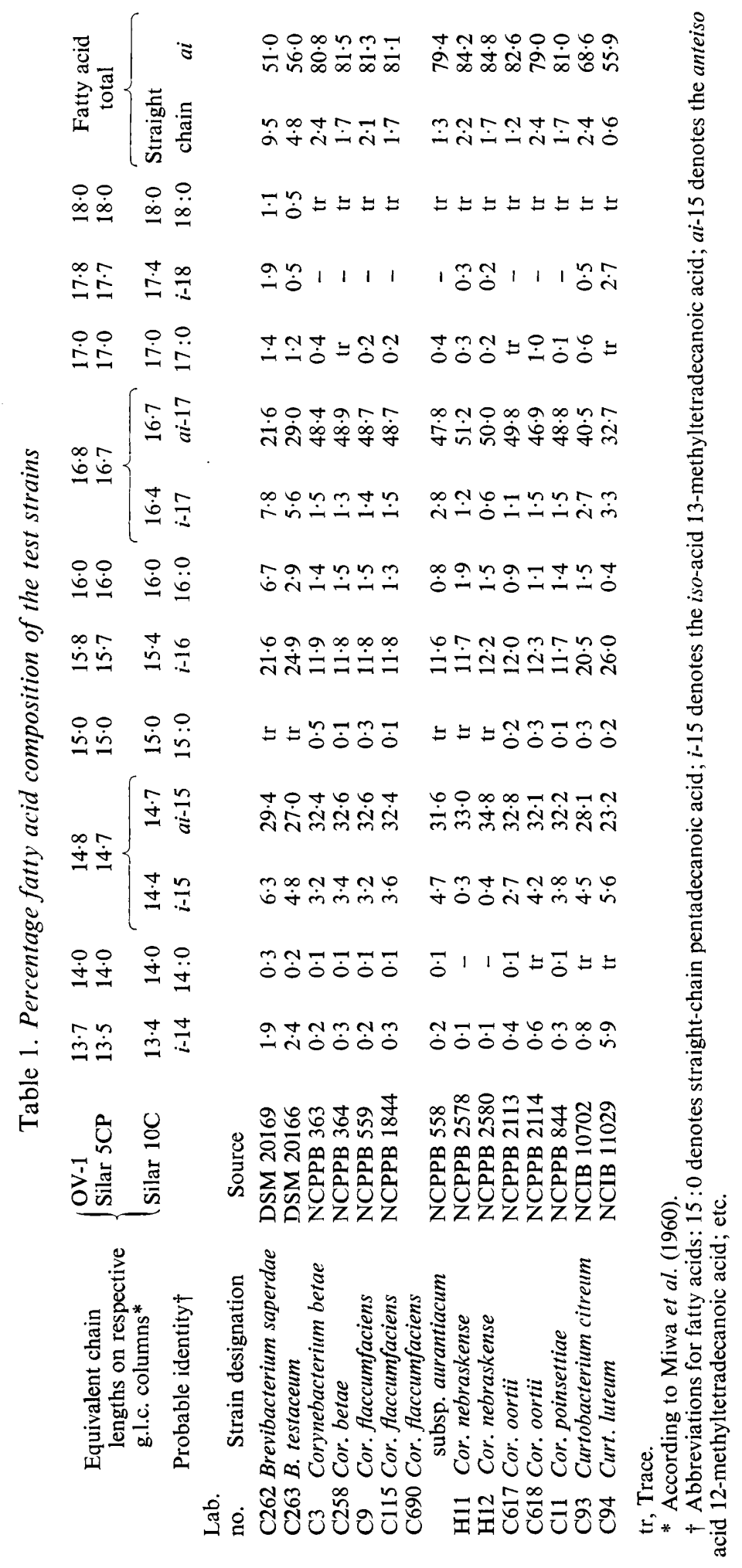




\section{Table 2. Peaks corresponding to molecular ions $\left(\mathrm{M}^{+}\right)$in the mass spectra of menaquinones isolated from the test strains}

The main component of each series is denoted by +++ , any component greater than $50 \%$ of the main peak by ++ and all other significant components by + .

\begin{tabular}{|c|c|c|c|c|c|c|}
\hline $\begin{array}{c}\text { Menaquinone isoprenologue } \\
\mathrm{m} / \mathrm{e}\end{array}$ & $\begin{array}{c}\text { MK-8 } \\
716\end{array}$ & $\begin{array}{c}\text { MK-9 } \\
784\end{array}$ & $\begin{array}{c}\mathrm{MK}-10 \\
852\end{array}$ & $\begin{array}{c}\text { MK-11 } \\
920\end{array}$ & $\begin{array}{l}\text { MK-12 } \\
988\end{array}$ & $\begin{array}{c}\text { MK-13 } \\
1056\end{array}$ \\
\hline Brevibacterium saperdae C262 & + & + & + & $++^{*}$ & $+t+$ & + \\
\hline B. testaceum $\mathrm{C} 263$ & + & + & + & $++t$ & ++ & + \\
\hline Corynebacterium betae $\mathrm{C} 3$ & + & +++ & - & - & - & - \\
\hline Cor, betae $\mathrm{C} 258$ & + & $+t+$ & - & - & - & - \\
\hline Cor. flaccumfaciens $\mathrm{C} 9$ & + & +++ & - & - & - & - \\
\hline Cor. flaccumfaciens $\mathrm{C} 115$ & + & +++ & - & - & - & - \\
\hline Cor. flaccumfaciens C690 & + & $+t+$ & - & - & - & - \\
\hline Cor. nebraskense $\mathrm{H} 11$ & + & $+t+$ & + & - & - & - \\
\hline Cor. nebraskense $\mathrm{H} 12$ & + & +++ & + & - & - & - \\
\hline Cor. oortii $\mathrm{C} 617$ & + & +++ & - & - & - & - \\
\hline Cor. oortii C618 & + & +++ & - & - & - & - \\
\hline Cor. poinsettiae $\mathrm{C} 11$ & + & +++ & - & - & - & - \\
\hline Curtobacterium citreum $\mathrm{C} 93$ & + & +++ & - & - & - & - \\
\hline Curt. luteum C94 & + & +++ & - & - & - & - \\
\hline
\end{tabular}

* Relative proportions of the isoprenologues were confirmed by reverse phase partition t.l.c.

$\mathrm{C}_{15}$ ) acids, with 14-methylpentadecanoic (iso $\mathrm{C}_{16}$ ) acid also present in fairly high proportions. The amount of iso $\mathrm{C}_{16}$ varied considerably among the test strains; substantially higher levels were found in Brevibacterium saperdae, B. testaceum, Curtobacterium citreum and Curt. luteum $(20.5$ to $26.0 \%$ ) than in the 'phytopathogenic corynebacteria' ( 11.6 to $12.3 \%$ ) (Table 1). The results of the present study are in accord with the previous report of high proportions of iso- and anteiso-methyl branched acids in Corynebacterium poinsettiae (Tadayon \& Carroll, 1971) and support the separation of Cor. betae, Cor. flaccumfaciens, Cor. flaccumfaciens subsp. aurantiacum, Cor. nebraskense and Cor. oortii from true corynebacteria which contain predominantly straight-chain and monounsaturated fatty acids (Asselineau, 1961; Blaschy \& Zimmermann, 1971; Alshamaony et al., 1977; Minnikin et al., 1978). Fatty acid analyses may also prove to be a reliable way of distinguishing curtobacteria from cellulomonads as the latter contain anteiso $\mathrm{C}_{15}$ as the major acid together with high proportions of straight-chain fatty acids (Minnikin et al., 1979).

Components that chromatographed with vitamin $\mathrm{K}$ were the only isoprenoid quinones detected in the test strains. On examination by ultraviolet spectroscopy the isoprenoid quinones displayed absorption maxima at 242, 248, 260, 270 and $326 \mathrm{~nm}$ in accordance with published data for menaquinones (Dunphy \& Brodie, 1971). The mass spectra of all the menaquinone samples showed intense peaks at $m / e 187$ and 225 derived from the naphthoquinone nucleus, as expected from published data (Azerad \& Cyrot-Pelletier, 1973). The mass spectra in the high mass region contained strong peaks corresponding to molecular ions $\left(\mathrm{M}^{+}\right)$, with smaller peaks at $\mathbf{M}^{+}-15$ corresponding to the loss of a methyl group from the molecular ion. Details of the mass spectral analyses of the menaquinones are shown in Table 2. The menaquinone composition of the test strains facilitated their division into two groups. Strains of Cor. betae, Cor. flaccumfaciens, Cor. flaccumfaciens subsp. aurantiacum, Cor. nebraskense, Cor. oortii, Cor. poinsettiae, Curt. citreum and Curt. luteum contained unsaturated menaquinones with nine isoprene units (abbreviated as MK-9) as the predominant isoprenologue, a result in accord with earlier studies (Collins et al., 1979, 1980). Brevibacterium (Curtobacterium) testaceum, however, contained MK-11 as the major isoprenologue together with substantial amounts of MK-12, thereby confirming the earlier work of Yamada et al. (1976). The single strain of B. saperdae examined also contained major amounts of MK-11 and MK-12 although the latter component predominated (Table 2). 


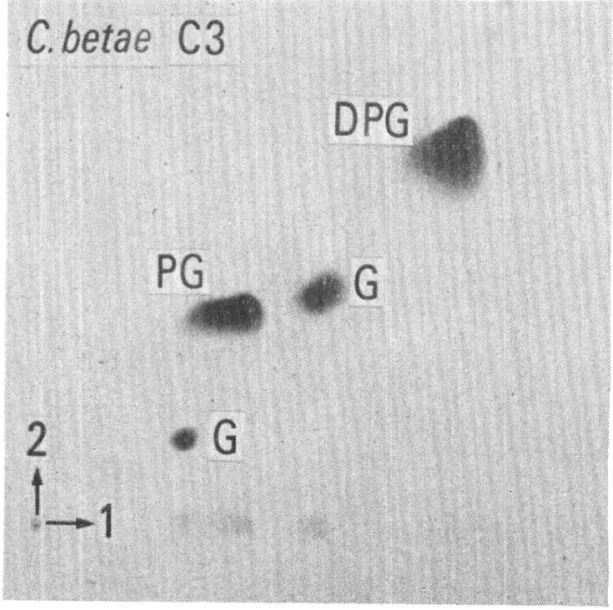

\section{C. betae $\mathrm{C} 258$}
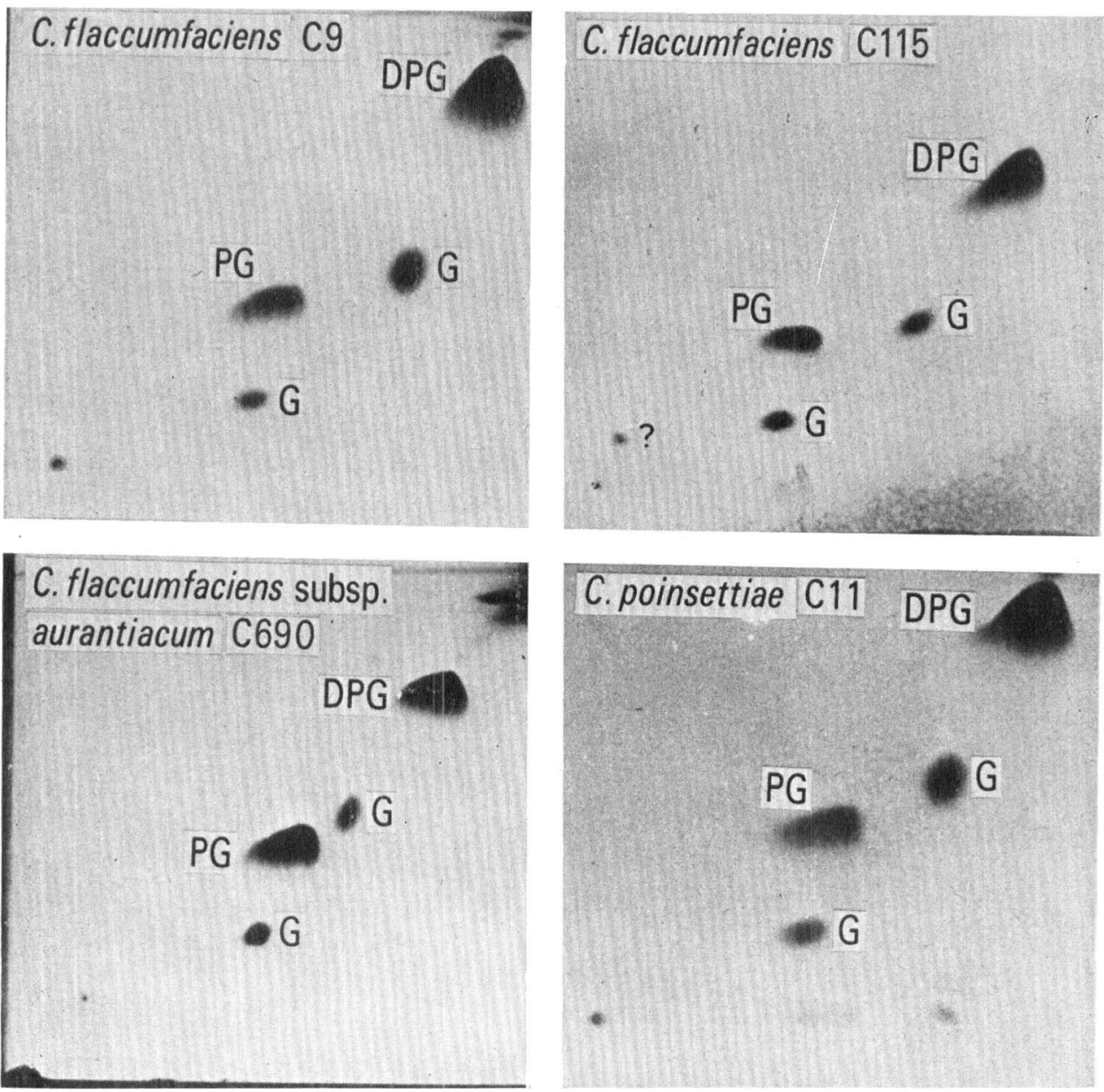

\section{C.poinsettiae C11 DPG}

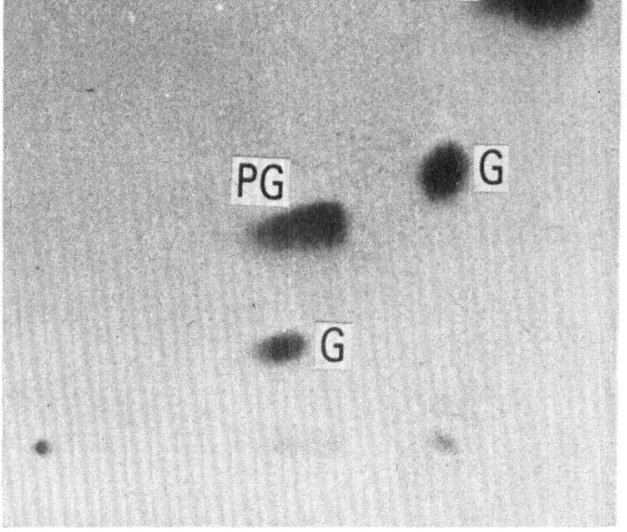

Fig. 1. Two-dimensional thin-layer chromatograms of polar lipids from Corynebacterium betae, Corynebacterium flaccumfaciens and Corynebacterium poinsettiae. Chloroform $/ \mathrm{methanol} /$ water $(65: 25: 4$, by vol.) was used in the first dimension, and chloroform/acetic acid/methanol/water $(80: 15: 12: 4$, by vol.) was used in the second dimension. Abbreviations: DPG, diphosphatidylglycerol; PG, phosphatidylglycerol; G, glycolipid. 

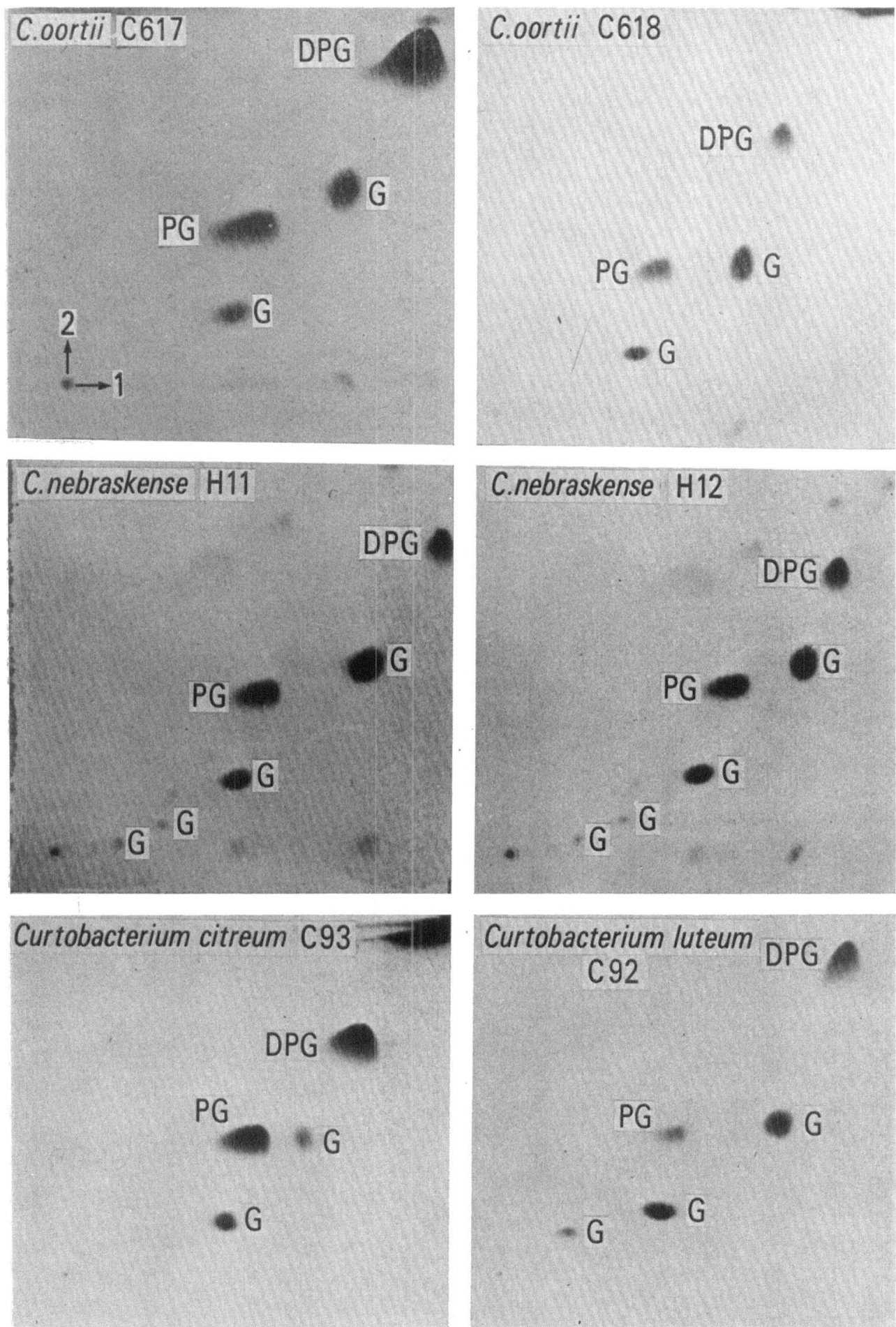

Fig. 2. Two-dimensional thin-layer chromatograms of polar lipids from Corynebacterium oortii, Corynebacterium nebraskense, Curtobacterium citreum and Curtobacterium luteum. Chloroform/ methanol/water ( $65: 25: 4$, by vol.) was used in the first dimension, and chloroform/acetic acid/ methanol/water ( $80: 15: 12: 4$, by vol.) was used in the second dimension. Abbreviations: DPG, diphosphatidylglycerol; PG, phosphatidylglycerol; G, glycolipid. 

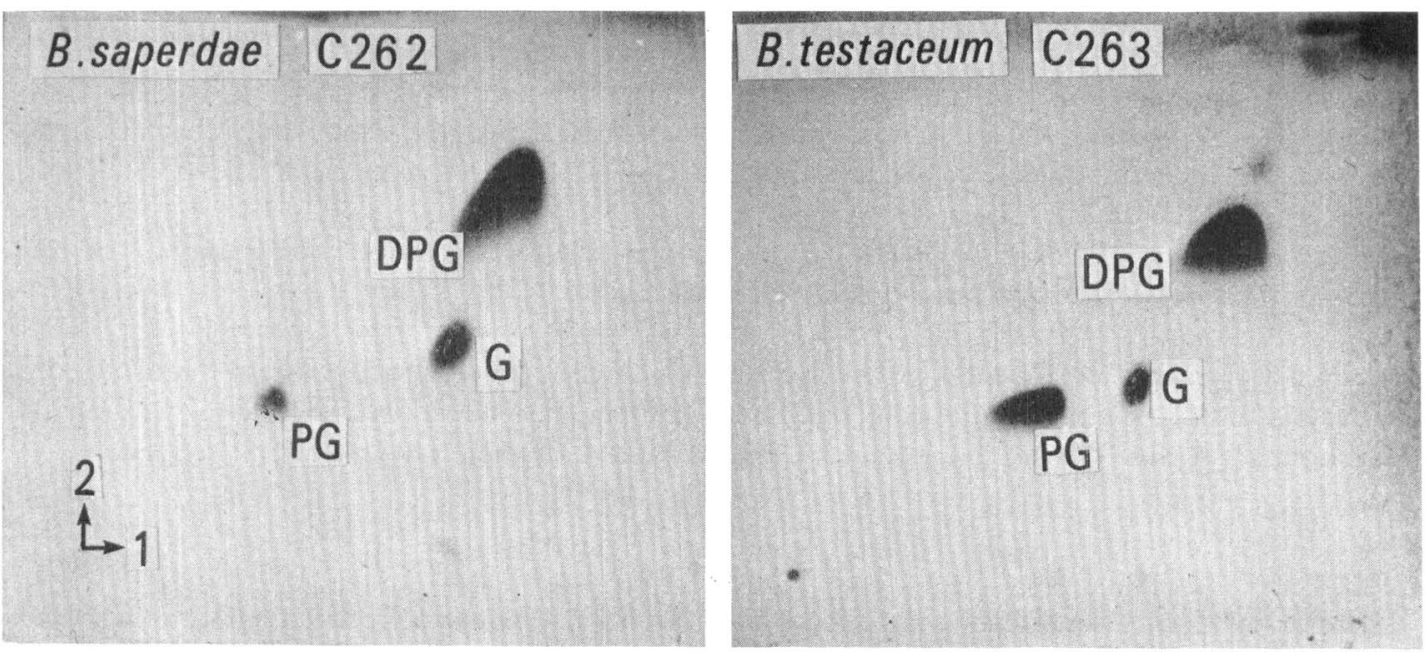

Fig. 3. Two-dimensional thin-layer chromatograms of polar lipids from Brevibacterium saperdae and Brevibacterium testaceum. Chloroform/methanol/water $(65: 25: 4$, by vol.) was used in the first dimension, and chloroform/acetic acid/methanol/water $(80: 15: 12: 4$, vol.) was used in the second dimension. Abbreviations: DPG, diphosphatidylglycerol; PG, phosphatidylglycerol; G, glycolipid.

Two distinct polar lipid patterns were also found in the test strains (Fig. 1, 2, 3). Diphosphatidylglycerol (DPG) and phosphatidylglycerol (PG) were readily identified in all extracts by their chromatographic behaviour and staining properties. A number of other characteristic lipids, which gave negative reactions to the lipid phosphorus and ninhydrin sprays but positive reactions to the periodate-Schiff and $\alpha$-naphthol reagents, were also detected in all of the strains. These unidentified glycolipids $(\mathrm{G})$ gave green coloration with the anisaldehyde/ $\mathrm{H}_{2} \mathrm{SO}_{4}$ reagent indicating the possible presence of mannose residues within these lipids. Curtobacterium citreum, Curt. luteum and the 'phytopathogenic corynebacteria' contained two or more of these unidentified glycolipids (Fig. 1,2) whereas B. saperdae and B. testaceum contained only a single glycolipid (Fig. 3). The only previous investigation of the polar lipid composition of curtobacteria and related strains was by Komura et al. (1975), who reported that Curt. albidum, Curt. citreum, Cor. flaccumfaciens and Cor. poinsettiae possess DPG, PG, phosphatidylinositol (PI) and an uncharacterized phosphatidylinositol mannoside (PIM). The detection of PI and PIM is at variance with the present results (Fig. 1) although Komura et al. (1975) did not investigate the possible presence of glycolipids in their strains.

The results of the present study support the inclusion of Cor. flaccumfaciens and Cor. poinsettiae in the genus Curtobacterium (Yamada \& Komagata, 1972) and suggest Cor. betae and Cor. oortii should also be added to the group. The recently described phytopathogen Cor. nebraskense (Vidaver \& Mandel, 1974) also has a lipid composition remarkably similar to that of curtobacteria. The numerical phenetic study of Dye \& Kemp (1977), however, indicated that Cor. nebraskense was quite distinct from the ornithine-containing taxa Cor. betae, Cor. flaccumfaciens and Cor. poinsettiae but shared a high affinity with Cor. michiganense and other diaminobutyric acid-containing taxa. Further comparative studies, including cell wall analyses, between Cor. nebraskense, curtobacteria and diaminobutyric acid-containing coryneform taxa are necessary to clarify the true taxonomic position of Cor. nebraskense.

Yamada \& Komagata (1972) proposed B. saperdae and B. testaceum should also be included in the genus Curtobacterium. The results of the present study, however, are at variance with this proposal. Curtobacteria should probably be restricted to those taxa 
having a peptidoglycan based on D-ornithine (variation B2 $\beta$ ) (Schleifer \& Kandler, 1972) and totally unsaturated menaquinones with nine isoprene units (Table 2). Brevibacterium saperdae and $B$. testaceum contain distinctively larger menaquinones (MK-11, MK-12) and these strains should be compared further with other ornithine-containing coryneforms (Arthrobacter flavescens, Corynebacterium barkeri, Microbacterium liquefaciens, etc.) of uncertain taxonomic position.

It can be concluded on the basis of lipid composition that the genus Curtobacterium as presently constituted represents a heterogeneous taxon.

We are grateful to Dr D. Jones, University of Leicester, for advice in the preparation of this manuscript. M.D.C. gratefully acknowledges receipt of a Luccock Scholarship (Medical Scholarships and Research Committee, Faculty of Medicine, Newcastle University).

\section{REFERENCES}

Alshamaony, L., Goodfellow, M., Minnikin, D. E., Bowden, G. H. \& Hardie, J. M. (1977). Fatty and mycolic acid composition of Bacterionema matruchotii and related organisms. Journal of General Microbiology 98, 205-213.

Asselineau, J. (1961). Sur quelques applications de la chromatographie en phase gazeuse a l'étude d'acides gras bactériens. Annales de l'Institut Pasteur 100, 109-119.

Azerad, R. \& Cyrot-Pelletier, M. O. (1973). Structure and configuration of the polyprenoid side chain of dihydromenaquinones from mycoand corynebacteria. Biochimie 55, 591-603.

BlASCHY, H. \& ZIMMERMANN, W. (1971). Gas-chromatographical investigations on fatty acids of various kinds of bacteria. Zentralblatt für Bakteriologie, Parasitenkunde, Infektionskrankheiten und Hygiene (Abteilung I, Originale) 218, 468477.

Bligh, E. G. \& DYer, W. J. (1959). A rapid method of total lipid extraction and purification. Canadian Journal of Biochemistry and Physiology 37, 911917.

CARD, G. L. (1973). Metabolism of phosphatidylglycerol, phosphatidylethanolamine and cardiolipin of Bacillus stearothermophilus. Journal of Bacteriology 114, 1125-1137.

Collins, M. D., Pirouz, T., Goodfellow, M. \& Minnikin, D. E. (1977). Distribution of menaquinones in actinomycetes and corynebacteria. Journal of General Microbiology 100, 221-230.

Collins, M. D., Goodfellow, M. \& Minnikin, D. E. (1979). Isoprenoid quinones in the classification of coryneform and related bacteria. Journal of General Microbiology 110, 127-136.

Collins, M. D., Shah, H. N. \& Minnikin, D. E. (1980). Separation of natural mixtures of bacterial menaquinones by reverse-phase partition thinlayer chromatography. Journal of Applied Bacteriology (in the Press).

CowAN, S. T. (1974). Manual for the Identification of Medical Bacteria, 2nd edn. Cambridge: Cambridge University Press.

DitTMer, J. C. F. \& Lester, R. L. (1964). A simple, specific spray for the detection of phospholipids on thin-layer chromatograms. Journal of Lipid Research 5, 126-127.
Dunphy, P. J. \& Brodie, A. F. (1971). The structure and function of quinones in respiratory metabolism. Methods in Enzymology 18, 407-461.

DYe, D. W. \& KeMP, W. J. (1977). A taxonomic study of plant pathogenic Corynebacterium species. New Zealand Journal of Agricultural Research 20, 563-582.

JaCin, H. \& Mishrin, A. R. (1965). Separation of carbohydrates on borate-impregnated silica gel $\mathbf{G}$ plates. Journal of Chromatography 18, 170-173.

JoNES, D. (1975). A numerical taxonomic study of coryneform and related bacteria. Journal of General Microbiology 87, 52-96.

KATES, M. (1972). Techniques of Lipidology. Amsterdam: North Holland Publishing Co.

KedDie, R. M. \& CuRE, G. L. (1977). The cell wall composition and distribution of free mycolic acids in named strains of coryneform bacteria and in isolates from various natural sources. Journal of Applied Bacteriology 42, 229-252.

Komagata, K., Iizuka, H. \& Uchino, C. (1964). Taxonomic comparison of four new species of Brevibacterium isolated from rice, and other related bacteria. Journal of the Agricultural Chemical Society of Japan 38, 503-509.

Komura, I., Yamada, K., Otsuka, S. \& Komagata, K. (1975). Taxonomic significance of phospholipids in coryneform and nocardioform bacteria. Journal of General and Applied Microbiology 21, 251-261.

LYSENKO, O. (1959). The occurrence of species of the genus Brevibacterium in insects. Journal of Insect Pathology 1, 34-42.

Minnikin, D. E. \& Abdolrahimzadeh, H. (1971). Thin-layer chromatography of bacterial lipids on sodium acetate-impregnated silica gel. Journal of Chromatography 63, 452-454.

Minnikin, D. E., Alshamaony, K. \& Goodfellow, M. (1975). Differentiation of Mycobacterium, Nocardia and related taxa by thin-layer chromatographic analysis of whole-organism methanolysates. Journal of General Microbiology 88, 100-204.

Minnikin, D. E., Goodfellow, M. \& Collins, M. D. (1978). Lipid composition in the classification and identification of coryneform and related taxa. In Coryneform Bacteria, pp. 85-160. 
Edited by I. J. Bousfield \& A. G. Callely. London : Academic Press.

Minnikin, D. E., Collins, M. D. \& Goodfellow, M. (1979). Fatty acid and polar lipid composition in the classification of Cellulomonas, Oerskovia and related taxa. Journal of Applied Bacteriology 47, 87-95.

Miwa, T. K., MikolajczaK, K. L., Earle, F. R. \& WolfF, I. A. (1960). Gas chromatographic characterization of fatty acids. Analytical Chemistry 32, 1739-1742.

Saaltink, G. L. \& Mass Geesteranus, H. P. (1969). A new disease in tulip caused by Corynebacterium oortii nov.sp. Netherlands Journal of Plant Pathology 75, 123-128.

Schleifer, K. H. \& Kandler, O. (1972). Peptidoglycan types of bacterial cell walls and their taxonomic implications. Bacteriological Reviews 36, $407-477$.

Shaw, N. (1968). The detection of lipids on thinlayer chromatograms with the periodate-Schiff reagent. Biochimica et biophysica acta 164, 435-436.
Stahl, E. \& Kaltenbach, U. (1961). Dünnschicht Chromatographie. VI Mitteilung. Spurenanalyse von Zuckergemischen auf Kieselgur G-Schichten. Journal of Chromatography 5, 351-355.

Tadayon, R. A. \& Carroll, K. K. (1971). Effect of growth conditions on the fatty acid composition of Listeria monocytogenes and comparison with fatty acids of Erysipelothrix and Corynebacterium. Lipids 6, 820-825.

Vidaver, A. K. \& Mandel, M. (1974), Corynebacterium nebraskense, a new, orange-pigmented phytopathogenic species. International Journal o Systematic Bacteriology 24, 482-485.

Yamada, K. \& Komagata, K. (1972). Taxonomic studies on coryneform bacteria. V. Classification of coryneform bacteria. Journal of General and Applied Microbiology 18, 417-431.

Yamada, Y., InOUYe, G., Tahara, Y. \& Kondo, K. (1976). The menaquinone system in the classification of coryneform and nocardioform bacteria and related organisms. Journal of General and Applied Microbiology 22, 203-214. 